\title{
Occurrence and Distribution of Triticum mosaic virus in the Central Great Plains
}

E. Byamukama, Department of Plant Pathology, University of Nebraska-Lincoln, Lincoln 68583; D. L. Seifers, Kansas State University, Agricultural Research Center-Hays, Hays 67601; G. L. Hein, Department of Entomology, University of Nebraska-Lincoln; E. De Wolf, Department of Plant Pathology, Kansas State University, Manhattan, KS 66506; N. A. Tisserat, Department of Bioagricultural Sciences and Pest Management, Colorado State University, Fort Collins 80523; M. A. C. Langham, Department of Plant Science, South Dakota State University, Brookings 57007; L. E. Osborne, Pioneer Hi-Bred International, Brookings, SD 57006; A. Timmerman, University of Nebraska Northeast Research \& Extension Center, Norfolk 68701; and S. N. Wegulo, Department of Plant Pathology, University of Nebraska-Lincoln, Lincoln

\begin{abstract}
Byamukama, E., Seifers, D. L., Hein, G. L., De Wolf, E., Tisserat, N. A., Langham, M. A. C., Osborne, L. E., Timmerman, A., and Wegulo, S. N. 2013. Occurrence and distribution of Triticum mosaic virus in the central Great Plains. Plant Dis. 97:21-29.

Wheat curl mite (WCM)-transmitted viruses-namely, Wheat streak mosaic virus (WSMV), Triticum mosaic virus (TriMV), and the High Plains virus (HPV) - are three of the wheat-infecting viruses in the central Great Plains of the United States. TriMV is newly discovered and its prevalence and incidence are largely unknown. Field surveys were carried out in Colorado, Kansas, Nebraska, and South Dakota in spring and fall 2010 and 2011 to determine TriMV prevalence and incidence and the frequency of TriMV co-infection with WSMV or HPV in winter wheat. WSMV was the most prevalent and was detected in $83 \%$ of 185 season-counties (= s-counties), $73 \%$ of 420 season-

fields (= s-fields), and $35 \%$ of 12,973 samples. TriMV was detected in 32,6 , and $6 \%$ of s-counties, s-fields, and samples, respectively. HPV was detected in 34,15 , and $4 \%$ of s-counties, s-fields, and samples, respectively. TriMV was detected in all four states. In all, $91 \%$ of TriMV-positive samples were co-infected with WSMV, whereas WSMV and HPV were mainly detected as single infections. The results from this study indicate that TriMV occurs in winter wheat predominantly as a double infection with WSMV, which will complicate breeding for resistance to WCM-transmitted viruses.
\end{abstract}

Winter wheat (Triticum aestivum L.) is an economically important crop in the Great Plains of the United States. In 2011, the Great Plains states of Colorado, Kansas, Nebraska, and South Dakota accounted for one-third of the total winter wheat production in the United States (13). Several viruses have been reported to infect winter wheat in this region, resulting in significant economic losses (12,27). They include Wheat streak mosaic virus (WSMV; 17), High Plains virus (HPV; 6), Barley yellow dwarf virus (14), Wheat spindle streak mosaic virus (24); Wheat soilborne mosaic virus (9), and Triticum mosaic virus (TriMV; 20). TriMV was discovered in 2006 in Kansas and subsequently shown to be transmitted by the wheat curl mite (WCM; Aceria tosichella Keifer) (19), which also transmits WSMV and HPV $(16,21,23)$.

WSMV and HPV, the two viruses known to be transmitted by WCMs before TriMV's discovery, are widespread in the Great Plains $(8,16)$. Recent studies have shown that co-infection of wheat with WSMV and TriMV results in synergism that increases symptom severity, elevates titers of both viruses (26), and exacerbates biomass and yield loss $(2,28)$. Therefore, knowing the extent of the distribution of TriMV and the frequency of its co-infection of wheat with WSMV or HPV will assist in estimating the potential risk TriMV poses to wheat production. Recently, field surveys in nine Great Plains states detected TriMV for the first time in Colorado, Montana, Nebraska, North Dakota, Oklahoma, South Dakota,

Corresponding author: S. N. Wegulo, E-mail: swegulo2@unl.edu

Accepted for publication 31 July 2012.

http://dx.doi.org/10.1094/PDIS-06-12-0535-RE

(C) 2013 The American Phytopathological Society
Texas, and Wyoming (1; M. Burrows, personal communication), indicating that the virus is widespread in the Great Plains of the United States. However, information is lacking on the prevalence and incidence of TriMV and the frequency of its co-infection of wheat with WSMV or HPV in individual states in the Great Plains region. The objectives of this study were to (i) conduct detailed wheat surveys in four central Great Plains states (Colorado, Kansas, Nebraska, and South Dakota) to determine the distribution and prevalence of TriMV and (ii) assess the incidence of occurrence of TriMV singly or in double or triple infections with WSMV and/or HPV.

\section{Materials and Methods}

Field surveys. Arbitrarily selected winter wheat fields were sampled in Colorado, Kansas, Nebraska, and South Dakota in spring 2010 and 2011; in Kansas, Nebraska, and South Dakota in fall 2010; and in Kansas and Nebraska in fall 2011 (Tables 1-3). In spring 2011, jointed goatgrass (Aegilops cylindrica Host.) was also collected from an area adjacent to a wheat field that had severe virus symptoms at a location in southwest Nebraska. In the spring, samples were collected from the current year's winter wheat crop. In the fall, samples were collected from volunteer wheat in fields previously cropped with winter wheat earlier during that year's growing season. Due to the low probability of finding volunteer wheat, fall sampling was not done in all states over the 2-year period. Fields in up to 31 counties were sampled in each state, and up to three fields were sampled in each county. In each field, up to 50 tillers were arbitrarily selected and collected. Although symptomatic tillers (with leaves showing greenish yellow, parallel, and discontinuous streaks) were targeted for collection, some asymptomatic tillers were collected as well. Symptoms at the field scale ranged from minimal ( $<1 \%$ incidence) to very severe (100\% inci- 
dence, with the entire field having a yellow cast). The tillers were placed in self-sealing bags which were labeled with date, field number, county, and state; kept on ice in a cooler; and transported to the laboratory, where they were kept at $4^{\circ} \mathrm{C}$. They were then mailed overnight or as soon as possible to the Agricultural Research Center, Kansas State University, Hays, where they were assayed for TriMV, WSMV, and HPV using enzyme-linked immunosorbent assay (ELISA).

Antiserum sources and control viruses. The TriMV antiserum was used as a whole serum at a 1:2,000 ( $\mathrm{vol} / \mathrm{vol})$ dilution prepared from a stock solution of protein at $1 \mathrm{mg} / \mathrm{ml}$ and was raised as described previously (20). WSMV antiserum $(1: 1,000$, vol/vol) (15) and HPV antiserum $(1: 1,000$, vol/vol) (HPV-WO) $(7,19) \mathrm{di}-$ lutions were made from stocks adjusted to protein at $1 \mathrm{mg} / \mathrm{ml}$.

Positive controls consisted of the 06-123 TriMV isolate (20), the Sidney 81 WSMV isolate (20), and the 06-Maize A HPV isolate $(7,19)$.

Indirect ELISA. Analyses used have been described previously (20). Plant tissue was ground in $800 \mu$ of coating buffer (3) in a 1.5-ml microcentrifuge tube using a wooden applicator stick

Table 1. Prevalence of Triticum mosaic virus (TriMV), Wheat streak mosaic virus (WSMV), or High Plains virus (HPV) at the county scale in Colorado, Kansas, Nebraska, and South Dakota in fall and spring 2010 and 2011

\begin{tabular}{|c|c|c|c|c|c|}
\hline \multirow[b]{2}{*}{ State, season } & \multirow[b]{2}{*}{ Total counties $(n)$} & \multicolumn{4}{|c|}{ County prevalence $(\%)^{\mathbf{a}}$} \\
\hline & & TriMV & WSMV & HPV & Combined $^{b}$ \\
\hline \multicolumn{6}{|l|}{ Colorado } \\
\hline Spring 2010 & 13 & 53.8 & 69.2 & 61.5 & 92.3 \\
\hline Spring 2011 & 12 & 50 & 100 & 58.3 & 100 \\
\hline All seasons & 25 & 52 & 84 & 60 & 96 \\
\hline \multicolumn{6}{|l|}{ Kansas } \\
\hline Spring 2010 & 2 & 0 & 50 & 0 & 50 \\
\hline Fall 2010 & 17 & 5.9 & 64.7 & 58.8 & 82.4 \\
\hline Spring 2011 & 22 & 63.6 & 95.5 & 31.8 & 95.5 \\
\hline Fall 2011 & 7 & 57.1 & 85.7 & 71.4 & 85.7 \\
\hline All seasons & 48 & 39.6 & 81.3 & 45.8 & 87.5 \\
\hline \multicolumn{6}{|l|}{ Nebraska } \\
\hline Spring 2010 & 28 & 25 & 85.7 & 25 & 85.7 \\
\hline Fall 2010 & 10 & 10 & 20 & 20 & 20 \\
\hline Spring 2011 & 32 & 50 & 96.9 & 21.9 & 96.9 \\
\hline Fall 2011 & 9 & 11.1 & 100 & 66.7 & 100 \\
\hline All seasons & 79 & 31.6 & 83.5 & 27.8 & 83.5 \\
\hline \multicolumn{6}{|l|}{ South Dakota } \\
\hline Spring 2010 & 16 & 12.5 & 93.8 & 12.5 & 93.8 \\
\hline Fall 2010 & 3 & 0 & 66.7 & 0 & 66.7 \\
\hline Spring 2011 & 14 & 0 & 78.6 & 7.1 & 78.6 \\
\hline All seasons & 33 & 6.1 & 84.8 & 9.1 & 84.8 \\
\hline Overall & 185 & 31.9 & 83.2 & 33.5 & 86.5 \\
\hline
\end{tabular}

${ }^{a}$ County prevalence was obtained by dividing the number of counties that had at least one sample positive for the respective virus by the total number of counties sampled in a state and multiplying by 100 .

${ }^{b}$ Combined county prevalence was obtained by dividing the number of counties that had at least one virus detected in a sample by the total number of counties sampled in a state and multiplying by 100 .

Table 2. Field prevalence of Triticum mosaic virus (TriMV), Wheat streak mosaic virus (WSMV), or High Plains virus (HPV) occurring alone or in combination in a field in Colorado, Kansas, Nebraska, and South Dakota in fall and spring 2010 and 2011

\begin{tabular}{|c|c|c|c|c|c|c|c|c|}
\hline \multirow[b]{2}{*}{ State, season } & \multirow[b]{2}{*}{ Total fields $(n)$} & \multicolumn{7}{|c|}{ Field prevalence $(\%)^{\mathrm{a}}$} \\
\hline & & TriMV & WSMV & HPV & TriMV+WSMV & WSMV+HPV & TriMV+WSMV+HPV & Combined $^{b}$ \\
\hline \multicolumn{9}{|l|}{ Colorado } \\
\hline Spring 2010 & 34 & 14.3 & 65.7 & 20.0 & 14.3 & 11.4 & 0 & 73.5 \\
\hline Spring 2011 & 53 & 5.7 & 77.4 & 11.3 & 28.3 & 5.7 & 11.3 & 79.2 \\
\hline Combined & 87 & 9.2 & 73.6 & 14.9 & 23.0 & 8.0 & 6.9 & 77.0 \\
\hline \multicolumn{9}{|l|}{ Kansas } \\
\hline Spring 2010 & 2 & 0 & 50.0 & 0 & 0 & 0 & 0 & 50.0 \\
\hline Fall 2010 & 27 & 0 & 53.8 & 30.8 & 3.8 & 23.1 & 0 & 69.2 \\
\hline Spring 2011 & 44 & 2.3 & 77.3 & 4.5 & 43.2 & 22.7 & 9.1 & 95.5 \\
\hline Fall 2011 & 19 & 5.3 & 68.4 & 63.2 & 26.3 & 15.8 & 0 & 89.5 \\
\hline Combined & 91 & 2.2 & 68.1 & 24.2 & 27.5 & 20.9 & 4.4 & 84.6 \\
\hline \multicolumn{9}{|l|}{ Nebraska } \\
\hline Spring 2010 & 57 & 8.8 & 75.4 & 17.5 & 7 & 3.5 & 0 & 75.4 \\
\hline Fall 2010 & 26 & 0 & 53.8 & 7.7 & 7.7 & 19.2 & 7.7 & 61.7 \\
\hline Spring 2011 & 57 & 14.0 & 94.7 & 8.8 & 52.6 & 7.0 & 0 & 94.7 \\
\hline Fall 2011 & 16 & 0 & 100 & 62.5 & 6.3 & 43.8 & 0 & 100 \\
\hline Combined & 156 & 8.3 & 81.4 & 17.3 & 23.7 & 11.5 & 1.3 & 82.7 \\
\hline \multicolumn{9}{|l|}{ South Dakota } \\
\hline Spring 2010 & 3 & 0 & 75.0 & 0 & 0 & 0 & 0 & 75.0 \\
\hline Fall 2010 & 33 & 2.9 & 60.0 & 0 & 2.9 & 5.7 & 0 & 60.0 \\
\hline Spring 2011 & 38 & 0 & 52.6 & 0 & 0 & 2.6 & 0 & 52.6 \\
\hline Combined & 74 & 1.4 & 71.6 & 0 & 1.4 & 4.1 & 0 & 71.6 \\
\hline Overall & 408 & 5.7 & 72.9 & 14.8 & 19.8 & 11.2 & 2.9 & 77.9 \\
\hline
\end{tabular}

${ }^{a}$ Field prevalence was obtained by dividing the number of fields that had at least one sample positive for the respective virus by the total number of fields surveyed in a state and multiplying by 100 . Single or mixed infections were detected in samples from fields in which more than one virus was found.

${ }^{\mathrm{b}}$ Combined field prevalence was obtained by dividing the number of fields that had at least one virus-positive sample by the total number of fields sampled in a state and multiplying by 100 . 
Table 3. Incidence of Triticum mosaic virus (TriMV), Wheat streak mosaic virus (WSMV), and High Plains virus (HPV) in winter wheat samples collected from Colorado, Kansas, Nebraska, and South Dakota in spring and fall 2010 and 2011

\begin{tabular}{|c|c|c|c|c|c|}
\hline \multirow[b]{2}{*}{ Season, state } & \multirow[b]{2}{*}{ Total samples $(n)$} & \multicolumn{4}{|c|}{ Incidence (\%) } \\
\hline & & TriMV & WSMV & HPV & All positive samples \\
\hline \multicolumn{6}{|l|}{ Spring 2010} \\
\hline Colorado & 1,885 & 1.0 & 16.8 & 3.3 & 20.1 \\
\hline Kansas & 69 & 0.0 & 8.7 & 0.0 & 8.7 \\
\hline Nebraska & 2,411 & 1.1 & 31.8 & 1.6 & 34.5 \\
\hline South Dakota & 1,098 & 0.2 & 32.9 & 0.4 & 33.5 \\
\hline All states & 5,463 & 0.8 & 26.6 & 1.8 & 28.6 \\
\hline \multicolumn{6}{|l|}{ Fall 2010} \\
\hline Kansas & 289 & 1.4 & 54.0 & 40.8 & 74.0 \\
\hline Nebraska & 645 & 1.1 & 24.5 & 3.9 & 25.0 \\
\hline South Dakota & 18 & 0.0 & 16.7 & 0.0 & 16.7 \\
\hline All states & 952 & 1.2 & 33.3 & 15.0 & 39.7 \\
\hline \multicolumn{6}{|l|}{ Spring 2011} \\
\hline Colorado & 1,199 & 30.0 & 52.0 & 6.1 & 54.8 \\
\hline Kansas & 335 & 27.5 & 91.0 & 11.9 & 92.8 \\
\hline Nebraska & 2,314 & 12.6 & 66.2 & 1.5 & 68.2 \\
\hline South Dakota & 1,857 & 0.0 & 3.4 & 0.1 & 3.4 \\
\hline All states & 5,705 & 13.0 & 44.2 & 2.6 & 45.7 \\
\hline \multicolumn{6}{|l|}{ Fall 2011} \\
\hline Kansas & 198 & 3.0 & 37.9 & 19.7 & 51.5 \\
\hline Nebraska & 655 & 0.2 & 32.5 & 18.5 & 46.3 \\
\hline All states & 853 & 0.8 & 33.8 & 18.8 & 47.5 \\
\hline \multicolumn{6}{|l|}{ All seasons } \\
\hline Colorado & 3,084 & 12.3 & 30.5 & 4.4 & 33.6 \\
\hline Kansas & 891 & 11.4 & 60.8 & 22.1 & 71.0 \\
\hline Nebraska & 6,025 & 5.4 & 44.3 & 3.6 & 47.2 \\
\hline South Dakota & 2,973 & 0.1 & 14.4 & 0.2 & 14.5 \\
\hline Overall & 12,973 & 6.2 & 35.3 & 4.3 & 38.1 \\
\hline
\end{tabular}

Table 4. Percentage of virus-positive samples for Triticum mosaic virus (TriMV), Wheat streak mosaic virus (WSMV), or High Plains virus (HPV) that were detected as single, double, or triple infections among states in spring and fall 2010 and 2011

\begin{tabular}{|c|c|c|c|c|c|c|c|}
\hline \multirow[b]{2}{*}{ State, season } & \multirow[b]{2}{*}{ Infection status } & \multicolumn{4}{|c|}{ Incidence $(\%)^{\mathbf{a}}$} & \multirow[b]{2}{*}{$\chi^{2 \mathrm{c}}$} & \multirow[b]{2}{*}{$P$ value } \\
\hline & & TriMV & WSMV & HPV & Combined $^{\mathbf{b}}$ & & \\
\hline \multicolumn{8}{|l|}{ Colorado } \\
\hline \multirow[t]{2}{*}{ Spring 2010} & Single & 50.0 & 85.7 & 94.3 & 95.3 & 43.01 & $<0.0001$ \\
\hline & Double & 50.0 & 14.3 & 5.7 & 4.7 & $\ldots$ & $\ldots$ \\
\hline \multirow[t]{3}{*}{ Spring 2011} & Single & 1.1 & 39.7 & 39.7 & 42.8 & 276.19 & $<0.0001$ \\
\hline & Double & 92.2 & 27.4 & 56.4 & 53.6 & $\ldots$ & $\ldots$ \\
\hline & Triple & 6.7 & 32.9 & 3.9 & 3.7 & $\ldots$ & $\ldots$ \\
\hline \multicolumn{8}{|l|}{ Kansas } \\
\hline \multirow{2}{*}{ Fall 2010} & Single & 0 & 41.0 & 49.2 & 70.1 & 7.36 & 0.0252 \\
\hline & Double & 100 & 59.0 & 50.8 & 29.9 & $\ldots$ & $\ldots$ \\
\hline \multirow[t]{3}{*}{ Spring 2011} & Single & 2.2 & 10.0 & 61.2 & 61.7 & 130.02 & $<0.0001$ \\
\hline & Double & 90.2 & 72.5 & 36.5 & 36.0 & $\ldots$ & $\ldots$ \\
\hline & Triple & 7.61 & 17.5 & 2.3 & 2.3 & $\ldots$ & $\ldots$ \\
\hline \multirow[t]{2}{*}{ Fall 2011} & Single & 16.7 & 76.0 & 66.7 & 82.4 & 9.62 & 0.0082 \\
\hline & Double & 83.3 & 24.0 & 33.3 & 17.6 & $\ldots$ & $\ldots$ \\
\hline \multicolumn{8}{|l|}{ Nebraska } \\
\hline \multirow[t]{2}{*}{ Spring 2010} & Single & 29.2 & 81.8 & 97.0 & 97.1 & 213.8 & $<0.0001$ \\
\hline & Double & 70.8 & 18.2 & 3.0 & 2.9 & $\ldots$ & $\ldots$ \\
\hline \multirow[t]{3}{*}{ Fall 2010} & Single & 0 & 80.8 & 10.3 & 82.9 & 101.39 & $<0.0001$ \\
\hline & Double & 69.2 & 17.3 & 75.9 & 15.1 & $\ldots$ & $\ldots$ \\
\hline & Triple & 30.8 & 2.2 & 13.8 & 2.0 & $\ldots$ & $\ldots$ \\
\hline \multirow[t]{2}{*}{ Spring 2011} & Single & 6.2 & 82.9 & 97.8 & 82.3 & $5,713.87$ & $<0.0001$ \\
\hline & Double & 93.8 & 17.1 & 2.2 & 17.7 & $\ldots$ & $\ldots$ \\
\hline \multirow[t]{2}{*}{ Fall 2011} & Single & 0 & 74.4 & 85.0 & 89.4 & 9.85 & 0.0073 \\
\hline & Double & 100 & 25.6 & 15.0 & 10.6 & $\ldots$ & $\ldots$ \\
\hline \multicolumn{8}{|l|}{ South Dakota } \\
\hline \multirow[t]{2}{*}{ Spring 2010} & Single & 50.0 & 0 & 98.6 & 98.6 & 162.56 & $<0.0001$ \\
\hline & Double & 50.0 & 100 & 1.4 & 1.4 & $\ldots$ & $\ldots$ \\
\hline \multirow[t]{2}{*}{ Fall 2010} & Single & 0 & 100 & 0 & 100 & $\ldots$ & $\ldots$ \\
\hline & Double & 0 & 0 & 0 & 0 & $\ldots$ & $\ldots$ \\
\hline \multirow[t]{2}{*}{ Spring 2011} & Single & 0 & 0 & 98.4 & 98.4 & 32 & $<0.0001$ \\
\hline & Double & 0 & 100 & 1.6 & 1.6 & $\ldots$ & $\ldots$ \\
\hline \multirow[t]{3}{*}{ Overall } & Single & 5.2 & 79.3 & 61.3 & 81.1 & $1,823.82$ & $<0.0001$ \\
\hline & Double & 90.5 & 20.0 & 34.2 & 18.2 & $\ldots$ & $\ldots$ \\
\hline & Triple & 4.3 & 0.7 & 4.9 & 0.7 & $\ldots$ & $\ldots$ \\
\hline
\end{tabular}

a Incidence was calculated as the percentage of virus-positive samples in single, double, or triple infections in a state and season.

${ }^{\mathrm{b}}$ Combined incidence was obtained by dividing the number of single, double, or triple infections by the total number of virus-positive samples in a state and season.

c The $\chi^{2}$ test examined the hypothesis that TriMV, WSMV, and HPV occurred in equal proportions as single, double, or triple infections. 
(Fisher Scientific). Rather than weighing each sample, a piece of tissue the length of the microfuge tube was used for each sample. This was done because of the large sample number and the varying tissue amounts in each sample, so that some tissue could be retained for back inoculations to wheat if a sample reacted with
TriMV antibodies. To provide an estimate of the range of sample dilutions, 50 such samples were weighed initially, resulting in sample dilutions of 1:9 (wt/vol) to 1:188 (wt/vol). Extracts $(200 \mu \mathrm{l})$ were placed in separate wells of ELISA plates (Immulon 1; Fisher Scientific) for $1 \mathrm{~h}$ at $37^{\circ} \mathrm{C}$. The wells were then rinsed with a buffer

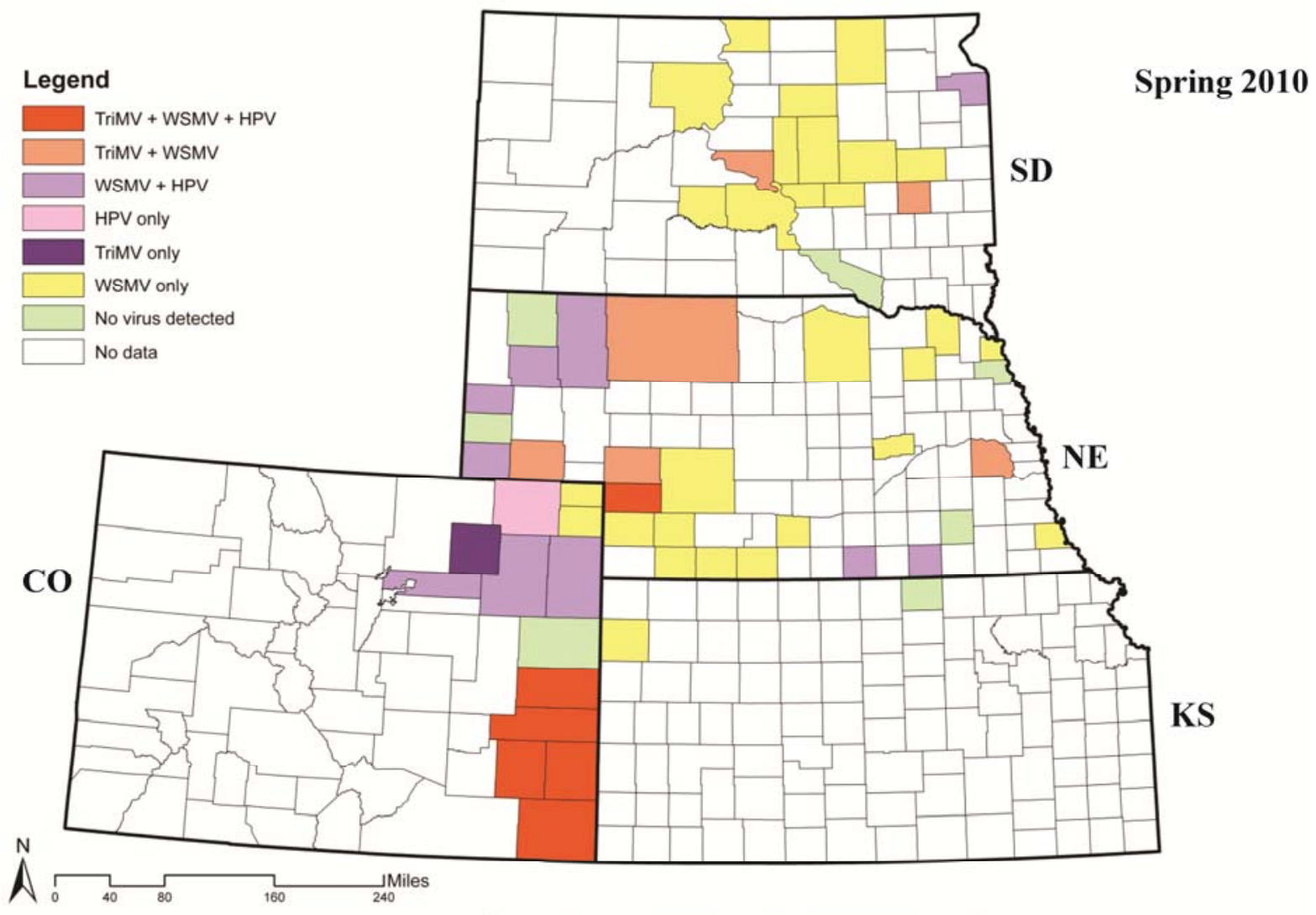

\section{Legend}

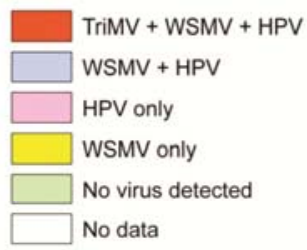

Fall 2010

\section{SD}

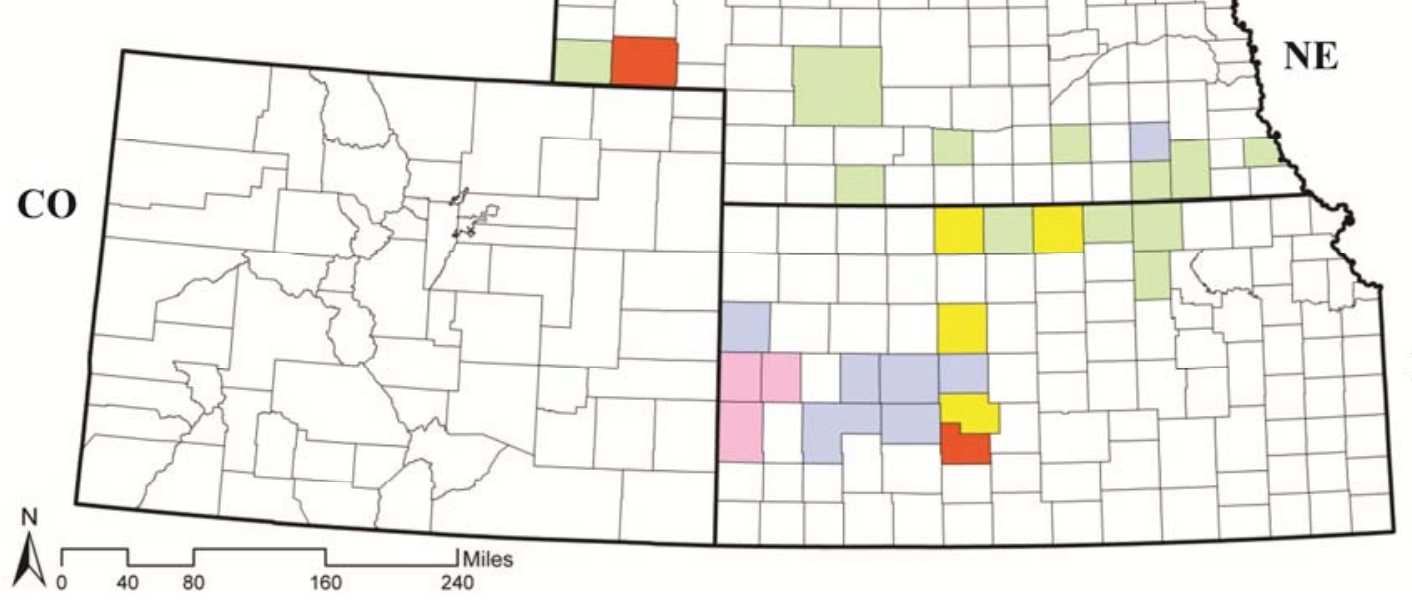

KS

Fig. 1. Occurrence of Triticum mosaic virus (TriMV), Wheat streak mosaic virus (WSMV), or High Plains virus (HPV) among four Great Plains states in spring and fall 2010. Single or mixed infections were detected in samples from counties in which more than one virus was found. 
consisting of $0.0137 \mathrm{M}$ sodium chloride, $0.147 \mathrm{mM}$ potassium phosphate, $0.81 \mathrm{mM}$ sodium phosphate, $0.269 \mathrm{mM}$ potassium chloride, $0.04 \mathrm{mM}$ Tween 20 , and $0.02 \%$ sodium azide, with $\mathrm{pH}$ adjusted to 7.4 using $1 \mathrm{~N} \mathrm{NaOH}$. Following the rinse, the wells were incubated for $1 \mathrm{~h}$ at $37^{\circ} \mathrm{C}$ with the appropriate antivirus antibody (as described above) in dilution buffer (3). The plates were then rinsed and blocked for $1 \mathrm{~h}$ in $1 \mathrm{ml}$ of blocking buffer (5\% nonfat dry milk, $0.01 \%$ antifoam $\mathrm{A}$, and $0.02 \%$ sodium azide in phosphate-buffered saline, $\mathrm{pH} 7.4$ ) at $37^{\circ} \mathrm{C}$. Then, $200 \mu \mathrm{l}$ of antirabbit antibody/alkaline phosphatase conjugate (Southern Bio-
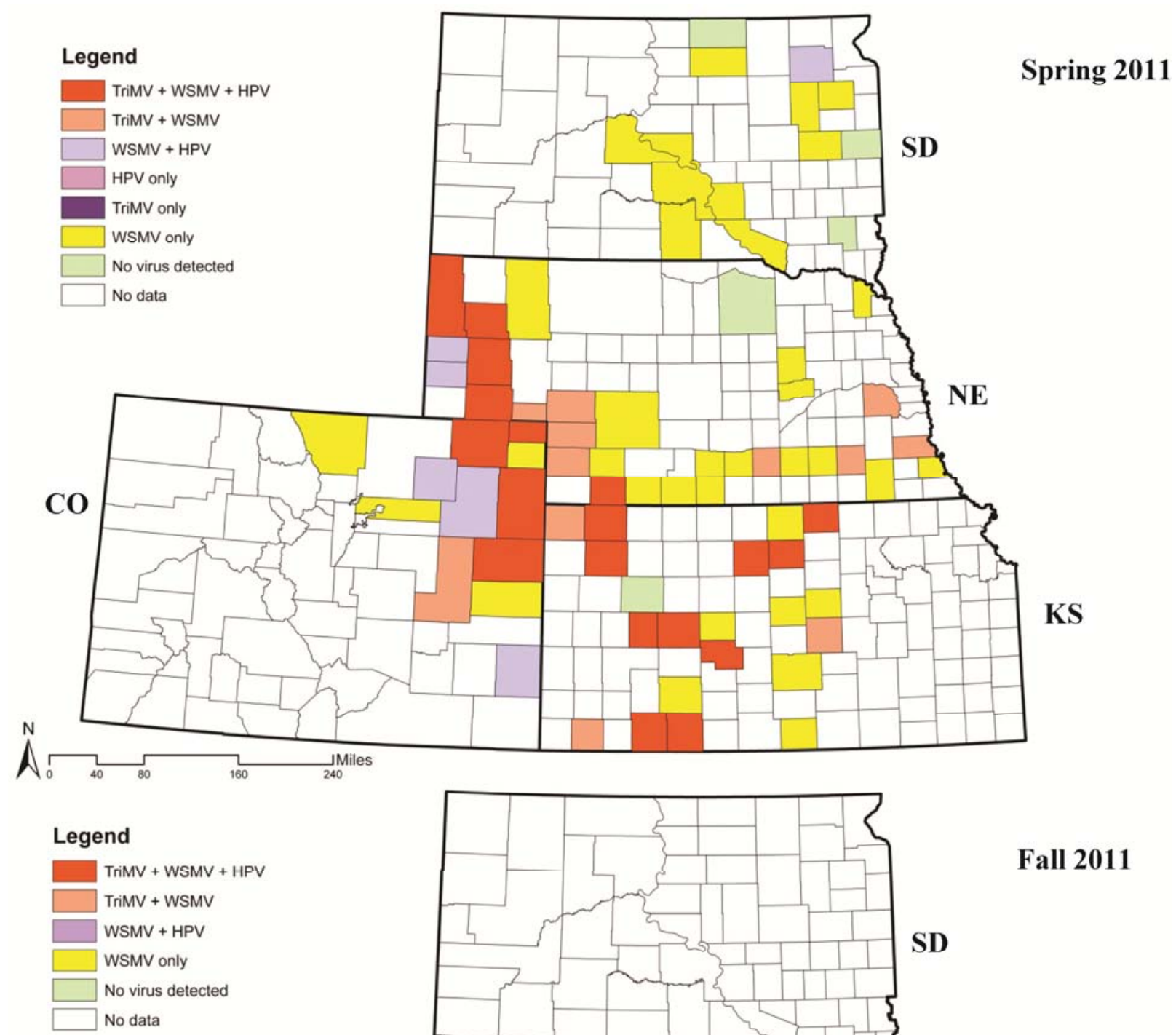
technology Associates) in dilution buffer (1:3,000 vol/vol) was added to each well. The plates were held at $37^{\circ} \mathrm{C}$ for $1 \mathrm{~h}$. The plates were rinsed, and $200 \mu \mathrm{l}$ of $\mathrm{p}$-nitrophenyl phosphate substrate in substrate buffer (3) at $0.714 \mathrm{mg} / \mathrm{ml}$ was added to each well. The plates were then held on a bench top at 20 to $22^{\circ} \mathrm{C}$ for $30 \mathrm{~min}$. Absorbance was measured at $405 \mathrm{~nm}$ using an iMark plate reader (Bio-Rad Laboratories). Absorbance values were arbitrarily considered positive if they were twice those of the healthy wheat leaf tissue.

Data analysis. Prevalence was calculated as the percentage of counties or fields with at least one sample testing positive for the respective virus. Incidence was calculated as the percentage of samples testing positive for single, double, or triple virus infections. Prevalence at the county scale was mapped with the ESRI ArcMap software (v.10; ESRI). The FREQUENCY procedure of SAS (SAS Institute) was used to test for equal occurrences of TriMV, WSMV, or HPV as single, double, or triple infections. The association of TriMV with WSMV or HPV was determined with the $\chi^{2}$ test and Cramer's $V^{2}$. A Cramer's $V^{2}$ value close to 1 indicates a strong association and a value close to 0 indicates a weak association (5).

\section{Results}

Virus distribution. In spring 2010, TriMV and HPV were detected in Colorado, Nebraska, and South Dakota but not in Kansas whereas WSMV was detected in all four states. In fall 2010 (Kansas, Nebraska, and South Dakota surveyed), TriMV and HPV were detected in Kansas and Nebraska, whereas WSMV was detected in all three states (Fig. 1). In spring 2011, TriMV was detected in Colorado, Kansas, and Nebraska but not in South Dakota, whereas WSMV and HPV were detected in all four states. In fall 2011 (Kansas and Nebraska surveyed), all three viruses were detected in both states (Fig. 2).

Virus prevalence. Over the four seasons during which virus surveys were conducted, TriMV, WSMV, and HPV occurred in 32, 83, and $34 \%$, respectively, of 185 season-counties (= s-counties) (Table 1). Overall virus prevalence at the county scale (percentage of counties in which at least one virus was detected) over the four seasons was $87 \%$. At the field scale, prevalence of TriMV, WSMV, and HPV was 6,73 , and $15 \%$, respectively, over the four seasons (Table 2). Prevalence of TriMV+WSMV, HPV+WSMV, and TriMV+WSMV+HPV at the field scale was 20,11 , and $3 \%$, respectively. Overall virus prevalence at the field scale (percentage of fields in which at least one virus was detected) over the four seasons was $78 \%$ (Table 2).

Virus incidence. Of 12,973 samples collected over the four seasons, the incidence of TriMV, WSMV, and HPV was 6, 35, and $4 \%$, respectively (Table 3 ). In all, $38 \%$ of the samples tested positive for at least one virus. Analysis of virus incidence by season showed that WSMV was the predominant virus in each season and state and that the incidence of TriMV was much higher in spring 2011 than in the other three seasons (Fig. 3; Table 3).

Single, double, and triple infections. Over the four seasons for all states, TriMV was detected predominantly (91\% of TriMVpositive samples) as a double infection with WSMV (Fig. 3; Table 4). These samples (doubly infected with TriMV and WSMV) in-

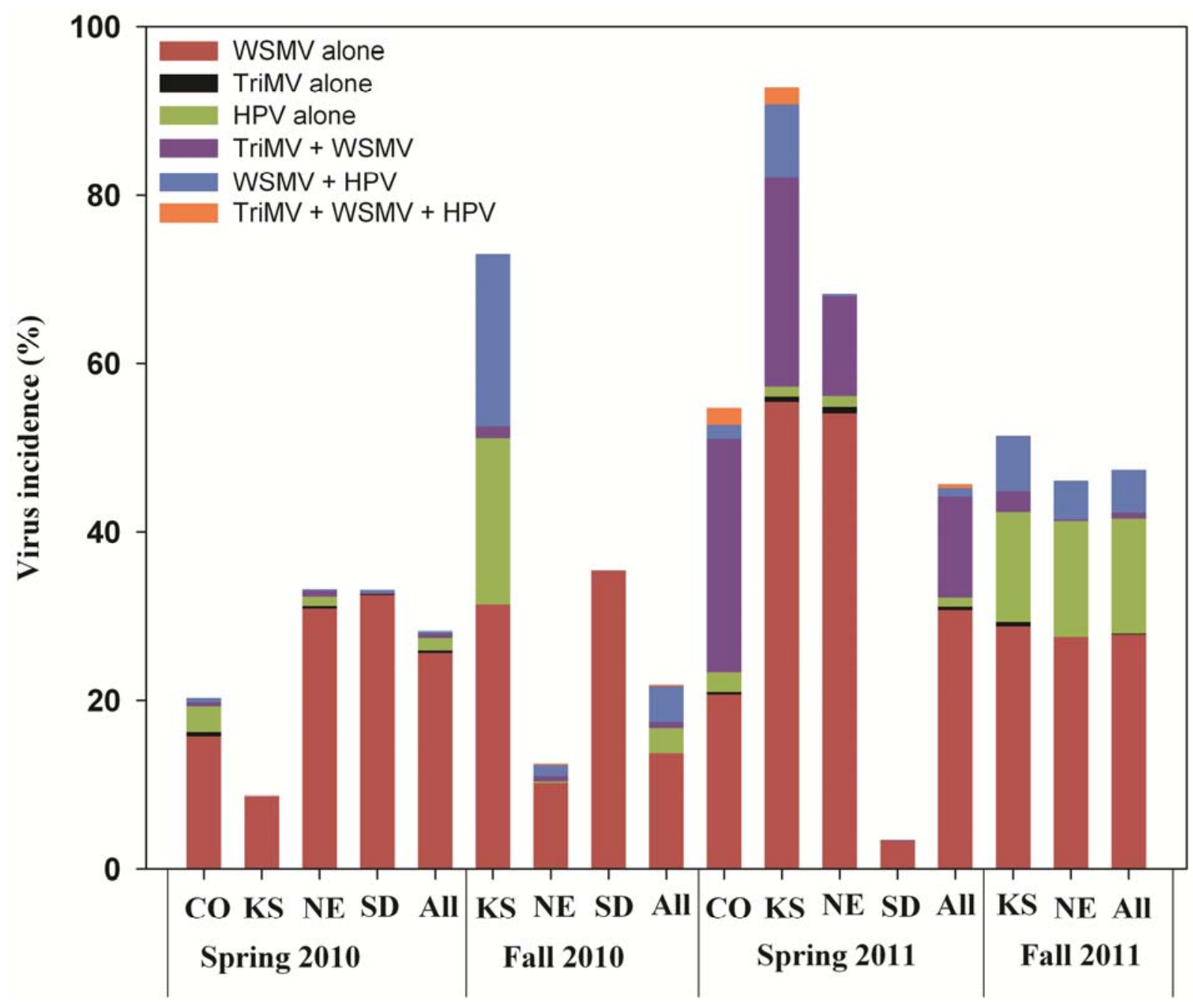

Fig. 3. Incidence of Triticum mosaic virus (TriMV), Wheat streak mosaic virus (WSMV), or High Plains virus (HPV) as single or mixed infections in winter wheat samples collected from fields in four Great Plains states in spring and fall 2010 and 2011. 
cluded the jointed goatgrass samples collected in southwest $\mathrm{Ne}$ braska in spring 2011. In contrast, WSMV and HPV were detected predominantly (79 and $61 \%$, respectively) as single infections. The incidence of WSMV and HPV occurring as double infections (WSMV+TriMV or WSMV+HPV) was 20 and 34\%, respectively, whereas the incidence of the three viruses occurring as a triple infection was less than $5 \%$. The $\chi^{2}$ test showed that, over the four seasons, the three viruses differed significantly $(P<0.0001)$ in their occurrence as single, double, or triple infections (Table 4).

Association between viruses in double infections. Double virus infections detected over the four seasons involved TriMV and WSMV or HPV and WSMV but not TriMV and HPV (Table 5). The $\chi^{2}$ test showed that associations between TriMV and WSMV and between HPV and WSMV were both significant $(P<0.0001)$. However, Cramer's $V$ statistic indicated that the association between TriMV and WSMV was much stronger than the association between HPV and WSMV.

\section{Discussion}

This study demonstrated that TriMV, a newly discovered WCMtransmitted virus of wheat originally reported in Kansas (20), is widely distributed in the central Great Plains states of Colorado, Kansas, Nebraska, and South Dakota. The current study involved detailed surveys to determine the distribution of TriMV and the other two WCM-transmitted viruses (WSMV and HPV) in each of the four states. Results indicated that, at the county and field scales, WSMV was the most prevalent, followed by HPV and TriMV, with the prevalence of the latter two viruses being much lower than that of WSMV. Overall incidence (percentage of the total number of samples testing positive for virus over the 2 years) was highest for WSMV (35\%) and lowest for TriMV (6\%) and HPV (4\%). In a 2008 Great Plains survey, Burrows et al. (1) similarly found that WSMV had the highest frequency of detection, followed by HPV and TriMV.

A higher percentage of samples were positive for at least one virus in spring 2011 compared with other seasons. This variability in virus incidence among seasons may be attributed to seasonal differences in weather conditions, including hail events. In Australia, Coutts et al. (4) reported a higher incidence of WSMV in a year when wind strength was high coupled with abundant grasses and volunteer cereals. The same study reported high WSMV incidence and WCM numbers when the preceding summer and autumn were wet, resulting in growth of grassy weeds and volunteer wheat, which are alternative hosts for WCMs and WSMV. Miller (11) reported that, in Wyoming, WSMV infection was most severe and losses were greatest in locations with volunteer wheat where hail had threshed maturing grain onto the ground the previous year. In Nebraska, Staples and Allington (25) reported a close association

Table 5. Association between Triticum mosaic virus (TriMV) and Wheat streak mosaic virus (WSMV), or High Plains virus (HPV) and WSMV, in winter wheat samples collected in spring and fall 2010 and 2011

\begin{tabular}{|c|c|c|c|c|c|}
\hline State, season & Virus combination & Incidence $^{\mathrm{a}}$ & $\chi^{2 b}$ & $P$ & $V^{2 \mathrm{c}}$ \\
\hline \multicolumn{6}{|l|}{ Colorado } \\
\hline \multirow[t]{2}{*}{ Spring 2010} & TriMV-WSMV & 50 & 15.02 & 0.0001 & 0.09 \\
\hline & HPV-WSMV & 14.3 & 0.21 & 0.65 & -0.01 \\
\hline \multirow[t]{2}{*}{ Spring 2011} & TriMV-WSMV & 98.9 & 471.14 & $<.00001$ & 0.63 \\
\hline & HPV-WSMV & 60.27 & 25.24 & $<.0001$ & 0.17 \\
\hline \multirow[t]{2}{*}{ All seasons } & TriMV-WSMV & 96.56 & 929.7 & $<0.0001$ & 0.55 \\
\hline & HPV-WSMV & 56.61 & 154.72 & $<0.0001$ & 0.22 \\
\hline \multicolumn{6}{|l|}{ Kansas } \\
\hline \multirow[t]{2}{*}{ Fall 2010} & TriMV-WSMV & 100 & 5.8 & 0.016 & 0.1558 \\
\hline & HPV-WSMV & 50.9 & 0.244 & 0.6211 & -0.029 \\
\hline \multirow[t]{2}{*}{ Spring 2011} & TriMV-WSMV & 97.8 & 8.66 & 0.0033 & 0.168 \\
\hline & HPV-WSMV & 90 & 0.16 & 0.6851 & 0.0255 \\
\hline \multirow[t]{2}{*}{ Fall 2011} & TriMV-WSMV & 83.33 & 7.79 & 0.0053 & 0.198 \\
\hline & HPV-WSMV & 33.3 & 0.0867 & 0.7684 & -0.0209 \\
\hline \multirow[t]{2}{*}{ All seasons } & TriMV-WSMV & 97.1 & 105.67 & $<0.0001$ & 0.344 \\
\hline & HPV-WSMV & 55.33 & 2.577 & 0.1084 & 0.1084 \\
\hline \multicolumn{6}{|l|}{ Nebraska } \\
\hline \multirow[t]{2}{*}{ Spring 2010} & TriMV-WSMV & 70.83 & 17.17 & $<0.0001$ & 0.0842 \\
\hline & HPV-WSMV & 18.18 & 0.168 & 0.6819 & 0.009 \\
\hline \multirow[t]{2}{*}{ Fall 2010} & TriMV-WSMV & 100 & 74.05 & $<0.0001$ & 0.214 \\
\hline & HPV-WSMV & 88 & 144.49 & $<0.0001$ & 0.298 \\
\hline \multirow[t]{2}{*}{ Spring 2011} & TriMV-WSMV & 93.8 & 114 & $<0.0001$ & 0.222 \\
\hline & HPV-WSMV & 17.14 & 29.81 & $<0.0001$ & -0.12 \\
\hline \multirow[t]{2}{*}{ Fall 2011} & TriMV-WSMV & $\ldots^{\mathrm{d}}$ & $\ldots$ & $\ldots$ & $\ldots$ \\
\hline & HPV-WSMV & 25.62 & 3.086 & 0.079 & -0.068 \\
\hline \multirow[t]{2}{*}{ All seasons } & TriMV-WSMV & 92.4 & 439.24 & $<0.0001$ & 0.25 \\
\hline & HPV-WSMV & 31.65 & 0.741 & 0.3893 & -0.01 \\
\hline \multicolumn{6}{|l|}{ South Dakota } \\
\hline Spring 2010 & HPV-WSMV & 100 & 8.19 & 0.0042 & 0.086 \\
\hline \multicolumn{6}{|l|}{ All states } \\
\hline \multirow[t]{2}{*}{ Spring 2010} & TriMV-WSMV & 61.36 & 28.08 & $<0.0001$ & 0.0718 \\
\hline & HPV-WSMV & 19 & 2.74 & 0.0978 & -0.02 \\
\hline \multirow[t]{2}{*}{ Fall 2010} & TriMV-WSMV & 100 & 73.87 & $<.0001$ & 0.198 \\
\hline & HPV-WSMV & 57.3 & 160.9 & $<0.0001$ & 0.29 \\
\hline \multirow[t]{2}{*}{ Spring 2011} & TriMV-WSMV & 96.8 & 979.8 & $<0.0001$ & 0.42 \\
\hline & HPV-WSMV & 58.39 & 31.43 & $<0.0001$ & 0.079 \\
\hline \multirow[t]{2}{*}{ Fall 2011} & TriMV-WSMV & 85.71 & 11.27 & 0.0008 & 0.12 \\
\hline & HPV-WSMV & 27.5 & 2.75 & 0.0972 & -0.057 \\
\hline \multirow[t]{2}{*}{ Overall } & TriMV-WSMV & 94.74 & 1467.56 & $<0.0001$ & 0.324 \\
\hline & HPV-WSMV & 39.1 & 30.57 & $<0.0001$ & 0.0468 \\
\hline
\end{tabular}

${ }^{a}$ Number of samples in which TriMV or HPV was detected together with WSMV divided by the total number of samples positive for the first virus multiplied by 100 .

${ }^{\mathrm{b}}$ The $\chi^{2}$ test examined the probability that the respective virus was or was not associated with WSMV.

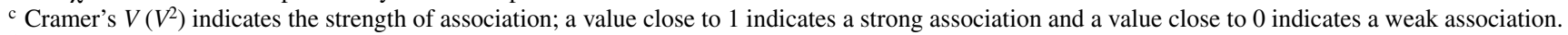

${ }^{\mathrm{d}}$ Insufficient number of samples; statistical analysis not performed. 
between hail injury in winter wheat and epidemics of WSMV in the following growing season in the areas where the hail occurred.

The finding in this study that the majority of TriMV-positive samples $(91 \%)$ were doubly infected with TriMV and WSMV was surprising and warrants further investigation. It is possible that, evolutionarily, one virus benefits from the other or the two viruses benefit from each other by co-occurring in the WCM vector or the wheat plant host. Potential benefits of such co-occurrence include increased transmission efficiency from the vector to the plant host (19), increased replication, or increased infectivity. Tatineni et al. (26) showed that co-infection of winter wheat with TriMV and WSMV resulted in disease synergism and an increase in the titer of both viruses, indicating a fitness advantage when both viruses cooccur in a host plant. However, this synergism, which increases the severity of symptom expression (yellowing), may work against the viruses or mite vector by killing the host (volunteer wheat) in the summer, before the wheat crop is planted in the fall. The high frequency of TriMV and WSMV double infections may also be due to presence of a mite biotype that efficiently transmits both viruses. G. L. Hein (unpublished) and McMechan (10) demonstrated differential transmission of TriMV and WSMV among three WCM biotypes collected from the Great Plains, with only one biotype efficiently transmitting both viruses.

The high incidence of TriMV-positive samples co-infected with TriMV and WSMV prompted us to analyze the association between TriMV and WSMV and between HPV and WSMV in the virus-positive samples over the 2-year period during which the study was conducted. This analysis showed that, although both associations were significant as determined from the $\chi^{2}$ test and Cramer's $V$ statistic, the association between TriMV and WSMV was much stronger than the association between HPV and WSMV. The reason for the strong association between TriMV and WSMV is not known and, as mentioned in the preceding paragraph, warrants further investigation.

In contrast to the high incidence of TriMV double infections, the majority of WSMV and HPV infections occurred as single infections, followed by double infections (WSMV+TriMV or WSMV+ HPV). Triple infections (WSMV+TriMV+HPV) were the least frequent. Burrows et al. (1) similarly found that, overall, most positive wheat plant samples had one virus present, with decreasing frequencies for co-infection with two, three, or four viruses. In the current study, co-infection of wheat samples with TriMV and HPV was not detected. However, Burrows et al. (1) detected wheat coinfection with TriMV and HPV in 13\% of samples tested. Coinfection of wheat with two or more viruses can result in increased disease severity and, consequently, a significant negative impact on yield. Tatineni et al. (26) demonstrated increased symptom severity and titer of each virus when winter wheat was co-infected with TriMV and WSMV. Similarly, Byamukama et al. (2) and Wegulo et al. (28) showed that, under greenhouse and field conditions, coinfection of a WSMV-susceptible winter wheat cultivar with TriMV and WSMV significantly reduced yield and yield determinants and components compared with single infections.

Samples of jointed goatgrass taken from an area adjacent to a wheat field with severe virus symptoms tested positive for both TriMV and WSMV. Jointed goatgrass is a known host for WSMV (22) and was shown to be susceptible to TriMV in an experimental host range study (18). In this study, TriMV occurrence in jointed goatgrass was a result of natural infection, indicating that this grass species can be a reservoir of TriMV in addition to WSMV.

This study demonstrated that TriMV, a recently discovered virus of wheat, is widespread in the central Great Plains states of Colorado, Kansas, Nebraska, and South Dakota. The virus occurred in winter wheat mainly as a double infection with WSMV. This finding has significant implications in that previous studies have shown increased symptom severity and exacerbated yield loss in winter wheat co-infected with TriMV and WSMV. Further research is needed to determine the reasons for the high incidence of TriMV occurrence as a double infection with WSMV in winter wheat.
Occurrence of the two viruses together may negate recent progress in breeding for resistance to WSMV and poses greater challenges in breeding for resistance to WCM-transmitted viruses.

\section{Acknowledgments}

Funding for this work was provided by the Agriculture and Food Research Initiative Competitive Grants Program Grant Number 2010-85605-20546 from the National Institute of Food and Agriculture. We thank J. Ackerman for his invaluable assistance in processing plant samples in all phases of the ELISA work.

\section{Literature Cited}

1. Burrows, M., Franc, G., Rush, C., Blunt, T., Ito, D., Kinzer, K., Olson, J., O'Mara, J., Price, J., and Tande, C. 2009. Occurrence of viruses in wheat in the Great Plains region, 2008. Plant Health Progress. Online publication. doi:10.1094/PHP-2009-0706-01-RS

2. Byamukama, E., Tatineni, S., Hein, G. L., Graybosch, R., Baenziger, P. S., French, R., and Wegulo, S. N. 2012. Effects of single and double infections of winter wheat by Triticum mosaic virus and Wheat streak mosaic virus on yield determinants. Plant Dis. 96:859-864.

3. Clark, M. F., and Adams, A. N. 1977. Characteristics of the microplate method of enzyme-linked immunosorbent assay for the detection of plant viruses. J. Gen. Virol. 34:475-483.

4. Coutts, B., Strickland, G., Kehoe, M., Severtson, D., and Jones, R. 2008 The epidemiology of Wheat streak mosaic virus in Australia: case histories, gradients, mite vectors, and alternative hosts. Aust. J. Agric. Res. 59:844853.

5. Gibbons, J. D. 1985. Nonparametric Methods for Quantitative Analysis, 2nd ed. American Sciences Press, Inc., Columbus, $\mathrm{OH}$.

6. Jensen, S. G., Lane, L. C., and Seifers, D. L. 1996. A new disease of maize and wheat in the High Plains. Plant Dis. 80:1387-1390.

7. Louie, R., Seifers, D. L., and Bradfute, O. E. 2006. Isolation, transmission and purification of the High Plains virus. J. Virol. Methods 135:214-222.

8. Mahmood, T., Hein, G. L., and Jensen, S. 1998. Mixed infection of hard red winter wheat with High Plains virus and wheat streak mosaic virus from wheat curl mites in Nebraska. Plant Dis. 82:311-315.

9. McKinney, H. H. 1953. Soilborne wheat mosaic viruses in the Great Plains. Plant Dis. Rep. 37:24-26.

10. McMechan, A. J. 2012. Transmission of Triticum mosaic virus and its impact on the biology of the wheat curl mite Aceria tosichella Keifer (Eriophyidae), and an evaluation of management tactics for the wheat curl mite and the wheat-mite-virus complex. M.S. thesis, University of $\mathrm{Ne}$ braska-Lincoln.

11. Miller, P. R. 1955. Plant disease situation in the United States. FAO Plant Prot. Bull. 3:58-59.

12. Nance, N. W. 1955. Some new and important plant disease occurrences and developments in the United States in 1954. Plant Dis. Rep. (Suppl.) 39:136175.

13. National Agricutural Statistics Service. 2011. Small Grains 2011 Summary. http://usda01.library.cornell.edu/usda/nass/SmalGraiSu//2010s/2011/SmalG raiSu-09-30-2011.pdf

14. Rochow, W. F. 1970. Barley yellow dwarf virus. In: Descriptions of Plant Viruses, No. 32. CMI/AAB, Kew, Surrey, UK.

15. Seifers, D. L. 1992. Partial characterization of a Colorado isolate of Agropyron mosaic virus. Plant Dis. 76:564-569.

16. Seifers, D. L., Harvey, T. L., Martin, T., and Jensen, S. G. 1997. Identification of the wheat curl mite as the vector of the High Plains virus of corn and wheat. Plant Dis. 81:1161-1166.

17. Seifers, D. L., and Martin, T. J. 1988. Correlation of low level Wheat streak mosaic virus resistance in Triumph 64 wheat with low virus titer. Phytopathology 78:703-707.

18. Seifers, D. L., Martin, D. J., and Fellers, J. P. 2010. An experimental host range for Triticum mosaic virus. Plant Dis. 94:1125-1131.

19. Seifers, D. L., Martin, T., Harvey, T. L., Fellers, J. P., and Michaud, J. 2009. Identification of the wheat curl mite as the vector of Triticum mosaic virus. Plant Dis. 93:25-29.

20. Seifers, D. L., Martin, T. J., Harvey, T. L., Fellers, J. P., Stack, J. P., RybaWhite, M., Haber S., Krokhin, O., Spicer, V., Lovat, N., Yamchuk, A., and Standing, K. G. 2008. Triticum mosaic virus: a new virus isolated from wheat in Kansas. Plant Dis. 92:808-817.

21. Seifers, D. L., Martin, T. J., Harvey, T. L., Haber, S., Krokhin, O., Spicer, V., Ying, S., and Standing, K. G. 2009. Identification of variants of the High Plains virus infecting wheat in Kansas. Plant Dis. 93:1265-1274.

22. Sill, W. H., Jr., and Connin, R. V. 1953. Summary of the known host range of wheat streak mosaic virus. Trans. Kans. Acad. Sci. 56:411-417.

23. Slykhuis, J. T. 1955. Aceria tulipe Keifer (Acarina: Eriophyidae) in relation to the spread of wheat streak mosaic. Phytopathology 45:116-128.

24. Slykhuis, J. T. 1976. Wheat spindle streak mosaic virus. In: Descriptions of Plant Viruses, No. 167. CMI/AAB, Kew, Surrey, UK.

25. Staples, R., and Allington, W. B. 1956. Streak mosaic of wheat in Nebraska and its control. Univ. Nebr. Agric. Exp. Stn. Res. Bull. 178

26. Tatineni, S., Graybosch, R. A., Hein, G. L., Wegulo, S. N., and French, R. 2010. Wheat cultivar-specific disease synergism and alteration of virus accumulation during co-infection with Wheat streak mosaic virus and Triti- 
cum mosaic virus. Phytopathology 100:230-238.

27. Velandia, M., Rejesus, R. M., Jones, D. C., Price, J. A., Workneh, F., and Rush, C. M. 2010. Economic impact of Wheat streak mosaic virus in the Texas High Plains. Crop Prot. 29:699-703.
28. Wegulo, S. N., Byamukama, E., Tatineni, S., Hein, G. L., Graybosch, R. A and Baenziger, P. S. 2012. Effects of single and double infections of winter wheat by Triticum mosaic virus and Wheat streak mosaic virus on grain yield and yield components. (Abstr.) Phytopathology 102:S4.134. 